\title{
PHENOMENOLOGICAL STUDY ON THE ADAPTABILITY OF INTERNATIONAL STUDENTS TO CONSERVATION-BASED CURRICULUM AT UNIVERSITAS NEGERI SEMARANG
}

\author{
Sandy Arief ${ }^{1}$ and Inaya Sari Melati ${ }^{2 *}$ \\ ${ }^{1} \mathrm{Mr}$, Universitas Negeri Semarang, INDONESIA, sandy.arief@mail.unnes.ac.id \\ ${ }^{2} \mathrm{Ms}$, Universitas Negeri Semarang, INDONESIA, inaya.sari@mail.unnes.ac.id \\ ${ }^{*}$ Corresponding author
}

\begin{abstract}
Universitas Negeri Semarang (UNNES) has a vision as a conservation university with international reputation. Therefore, UNNES implements learning activity by applying character development of conservation. In developing the character of the entire academic community, UNNES applies transformative learning by changing the orientation of anthropocentrism to eco-centrism learning (constructivism and cooperative approach in line with the eco-centrism orientation), from selfishness to collectivism, and materialism to spiritualism. Furthermore, UNNES uses learning strategies includingrole model, habituation, reinforcement, and reflective thinking. This study aims to identify and analyze the adaptability of international students in both academic and social issues related to conservation-based curriculum at UNNES. Participants in this study were 52 students from 13 countries. This research used descriptive qualitative by phenomenological approach. Whereas, the data was obtained from observation and in-depth interview. Perception of international student to the curriculum in UNNES is described and expected to be used as a platform for policy makers to make innovations in an attempt to create UNNES as a conservation university with international reputation. Based on the results, international students can adapt well in UNNES environment, both in academic and social issues. International students are able to understand and implement 8 conservation characters of UNNES; there are inspiring, humane, caring, innovative, creative, fair play, honest and fair. Theyalso appreciate the concept of Student Centre Learning (SCL) in UNNES and stated that the learning principles have been well implemented in UNNES. Nevertheless, language remains a constraint and thus interactive and participatory principles may not be implemented optimally. Hence, lecturers are expectedto improve their English skill to overcome this language constraint and create participative communication with their international students. Also, International Office (IO) may need to further demonstrate its role in creating mutual understanding between the two parties and providing facilities for international students to adapt in UNNES environment, since the international students have not gain significant benefit from its existence.
\end{abstract}

Keywords: academic adaptation, social adaptation, international students 


\section{INTRODUCTION}

Universitas Negeri Semarang (UNNES) proposes a vision to be a conservation minded university with international reputation, therefore UNNES continue to improve its curriculum based on four principles; there are conservation character development, competency development, balance, and equality of learning outcomes (BPM UNNES, 2015). The principle that became the distinctive character of UNNES is character development of conservation. In developing the character of the entire academic community, UNNES applies transformative learning by changing the orientation of anthropocentrism to eco-centrism learning (constructivism and cooperative approach in line with the eco-centrism orientation), from selfishness to collectivism, and materialism to spiritualism. Furthermore, UNNES uses learning strategies including role model, habituation, reinforcement, and reflective thinking.

Conservation-based curriculum implemented in UNNES is a manifestation of the Indonesia's cultural values. Thus, these cultural values will be strange and become something newfor international students. On the other hand, to gain international reputation, it is necessary to improve international cooperation with foreign universities. For instance, by increasing the number of students who join student exchange program.

In 2016, UNNES has 52 foreign students from 13 different countries, including Turkey, Libya, Krygistan, Venezuela and other countries. Foreign students add diversity within the academic community in Unnes. In addition, foreign students experience with new cultures has an important psychological implication in their performance and function (Robie\& Ryan, 1996). They have their own perspective in academic and social issues.

Several studies have found some problems faced by foreign students. Sato and Hodge (2015) stated that Japanese students have difficulty in mastering the learning material on their majors at the University in the United States due to their limited English skill. Finding of Brown (2008) supported the research of Sato and Hodge. He described that students studying abroad witnessed increases in their stress levels because of their poorcompetence in English and a high cultural difference between their original country and the country they study in.

Moreover, foreign students do not only meet academic problems, but also social barriers in their studies. Saeir, et al (2007) suggested that two-thirds of foreign students in Australia were having problems with their sense of isolation due to difficulties in communication with the family and their friends. Similar problems experienced by Japanese students studying in the United States, they feel isolated from their classmates and professors do not serve them well (Sato and Hodge, 2015).

Research into the experiences of foreign students studying in UNNES is important to understand their condition, and thus policies can be formulated to improve their adaptability both academically and socially. Therefore, it is necessary to study the factors that affect the adaptability of foreign students academically and socially.

\section{LITERATURE REVIEW}

\subsection{Theory of Adaptation}

Adaptation is an attempt of personal adjustment to the surrounding environment. The adjustment means changing self in accordance with the state of the environment, or changing the state of the environment in accordance with the personal desires (Gerungan, 1991). In the survival of humans as social beings, humans need a relationship to establish regularity, not to feel isolated and able to learn the culture (Suparlan, 1993).

Cross-cultural adaptation process involving a change of identity and barriers for international students. The barriers are as follows: (1) differences in core beliefs, values, and situational norms between the original place and new place; (2) loss of original culture and all the familiar images and symbols indicating that once familiar identity of the newcomers have been lost; (3) sense of inability of migrants in response to new regulations appropriately and effectively. On the other hand, there are process that supports the social adaptation, such as: (1) peace and increased self-esteem; (2) flexibility and cognitive openness; (3) competence in social interaction and increased in self-confidence and trust others (Winata, 2014).

\subsection{Curriculum of UNNES 2015}

Based on the curriculum guidelines issued by the Quality Assurance Agency (BPM) UNNES, curriculum of UNNES in 2015 has been harmonized with National Job Framework of Indonesia (Kerangka Kerja Nasional Indonesia/KKNI) and conservation, in accordance with the vision of UNNES to be a conservation university with international reputation. UNNES Curriculum 2015 is designed to produce graduates who have the character of conservation; there are inspiring, humanism, caring, innovative, creative, fair play, honest, and 
fair. In addition, the parameters in learning outcomes based on KKNI consist of attitudes, general skills, specialized skills and knowledge.

Learning principle is a pattern illustrates the interaction between students and faculty and between students and learning resources in the learning environment in UNNES. The learning principle which is selected and expected to be implemented by the lecturers is called Student Centred Learning (SCL). SCL is applied in a systematic and structured through a variety of subjects with measurable learning load and use effective learning methods based on the characteristics of each subjects. There are 12 principles of SCL: exemplary, equality, interactive, inspiring, participatory, integrated, comprehensive, implementable, contextual, educate, motivate and learning by doing.

\subsection{Research Framework}

Research framework in this paper can be described as follows:

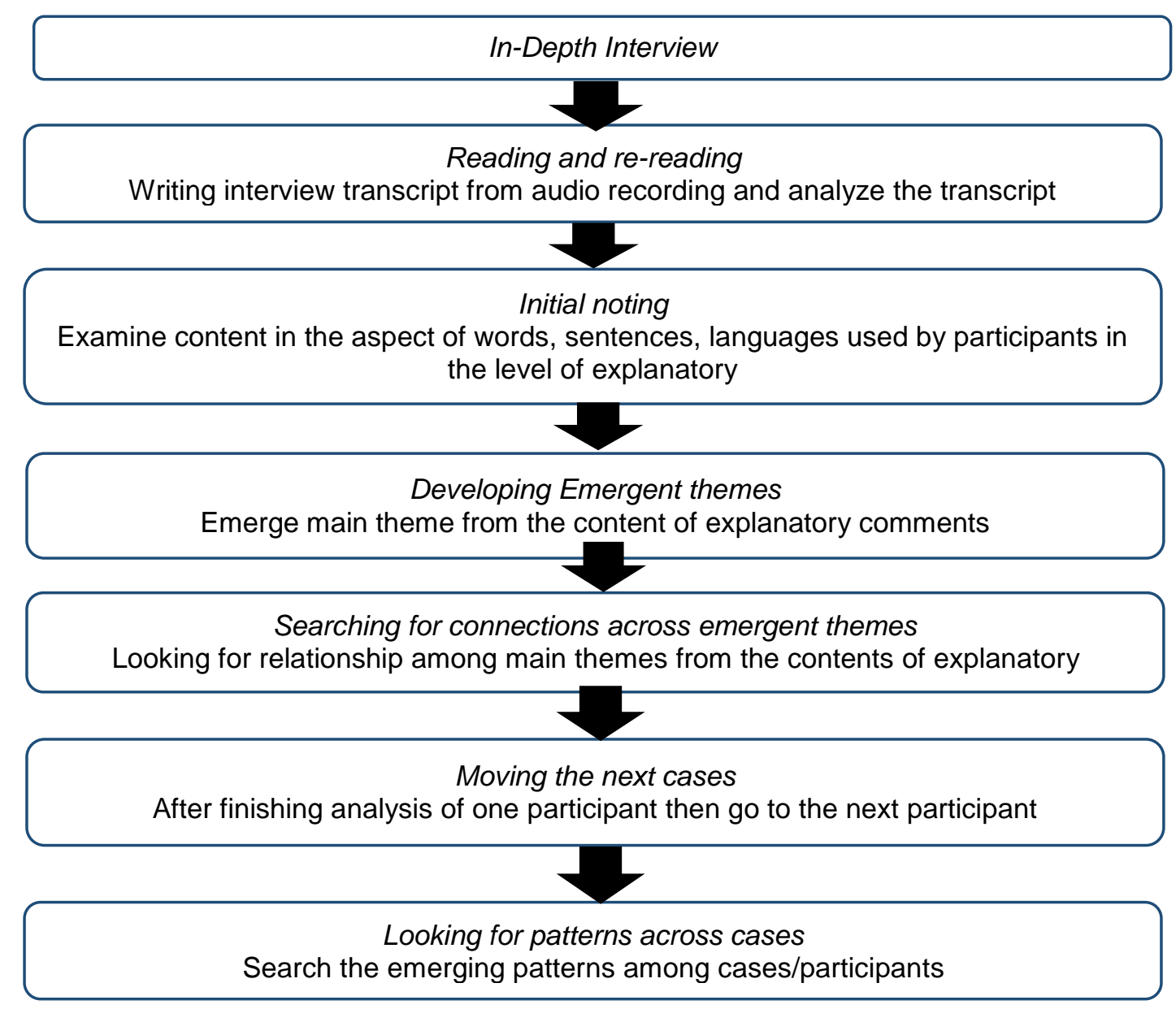

Fig. 1.Research Framework

\section{METHODOLOGY}

\subsection{Types of research and Research Approach}

This study is a qualitative research with phenomenological approach. The main concept in phenomenology is the meaning. Meaning is an important content that emerged from the experience of human consciousness. Identification the essential quality of consciousness experience is accomplished thoughtfully and thoroughly (Smith and Osborn, 2009). This phenomenological study is assisted by Interpretative Phenomenological Analysis (IPA), which aims to reveal in detail how participants interpret their personal and social environment.

The focus of this study was described in twofold: 1) description of the phenomenological perception of international students on the values of conservation character as the hallmark and excellence UNNES 
output; and 2) a phenomenological description of the international students on the learning principles of UNNES conservation curriculum.

\subsection{Population and Sample}

The study population is students who are members of Darmasiswa (international students) either bachelor or master degree at UNNES. Samples selected were 4 students who come from Libya (representing Africa), Turkey (representing Europe), Tajikistan and Vietnam (representing Asian). The samples were gained by implementing purposive sampling technique.

\subsection{Data Analysis Method}

In this study, the data were collected by observation and in-depth interviews. In depth interview in phenomenological research means to look for something meaningful thoughtfully to gain a detailed understanding of the social and educational phenomenon study. The questions proposed in the in-depth interview represent the indicators of two constructs examined in this study, there are: perception of international students on conservation-based curriculum and learning principles. Indicators of conservationbased curriculum is conservation character created by UNNES, there are: inspiring, humanism, caring, innovative, creative, fair play, honest, and fair. Furthermore, the indicators of learning principles is adjusted to Student Centred Learning (SCL) as UNNES learning principles, which include: exemplary, equality, interactive, inspiring, participatory, integrated, comprehensive, implementable, contextual, educate, motivate, and learning by doing.

The data obtained by in-depth interview can be analysed with the Interpretative Phenomenological Analysis (IPA), as written by Smith and Osborn (2009). Stages of IPA carried out in this study are as follows: 1) reading and re-reading; 2 ) initial noting; 3 ) developing emergent themes; 4) searching for connections across emergent themes; 5) moving the next cases; and 6) looking for patterns across cases.

\section{RESULTS AND DISCUSSION}

\subsection{Description of Research Participants}

Participants in this study were four Darmasiswa from three different continents. This sample election of such participants is directed to explore the perceptions of each participant with different cultural backgrounds. It is intended to obtain impartial information from different points of view, therefore the final conclusions can be drawn from valid triangulation result.

First participant was RB, a student of third semester master degree in the Faculty of Economics UNNES from Libya, North Africa. Second participant was a ninth semester student studying in the Department of Management, Faculty of Economics UNNES named AS. AS came from Tajikistan, Central Asia and studying bachelor degree in UNNES with a scholarship from the Government of Tajikistan. The third participant was a student of Arabic Language Department, Faculty of Language and Arts seated in seventh semester. Also, the last participant was TA from Vietnam, a Darmasiswa scholarship awardee to learn Bahasa and culture of Indonesia for a year in the Department of Indonesian Language and Literature, Faculty of Language and Arts.

\subsection{Results and Discussion}

Based on in-depth interviews with participants, they admitted that they love their presence in Indonesia and they were very keen to learn the culture of the archipelago. There are several things that make them interested in studying in Indonesia, especially in Universitas Negeri Semarang. For instance, because of a recommendation from a friend, hospitality, Indonesian and traditional culture.

\section{"...because people here are so kind, you know"}

They felt a significant cultural difference between Indonesia and their home country, however they had claimed to be able to adapt pretty well. Basically, international students will indeed tend to make selfadjustments in order to reach their academic target they expected (Hubs, 2014).

This study focuses on understanding and perception of international students on conservation-based curriculum and learning principles in UNNES. Characters of conservation studied here including 8 characters, which are inspiring, humane, caring, innovative, creative, fair play, honest and fair. The first character, which is inspiring, has been able to be implemented by the participants. All participants stated that the lecturers in UNNES inspire them to be kind and help friends, create something useful for others, and selfdevelopment. 
In terms of humanist character, international students of UNNES stated that they never involved in conflicts with friends or people in the neighbourhood. This was disclosed by AS:

"No, there's no conflict. I think everybody (has thought, red) which according to every person was right, so everyone should understand others. Definitely others think he is definitely right, we just have to understand."

They were able to maintain good relationship with everyone. They maintained understanding and tolerance of different opinion with the people around. Nevertheless, they admitted that they had limited friendship. Sato and Odge (2015) also revealed a similar thing. International students tend to interact and communicate closely with his colleagues who come from the same country. In UNNES, international students have few friends from Indonesia and a few friends from his home country. This has certainly an impact on their perceptions of the care characters. Because of their limited friendship, international students tend to riveted on their original culture that leads to individualism. Therefore, most of the international students are less concerned with his colleagues on campus because they consider that self-interest is individual authority and should not be interfered by others. However, they said they would be satisfied to help if any of their friends need a help, especially in terms of academic, as revealed by EM:

"We must be good (to others), (have a good) friendship, (and) have best friends."

From the aspect of innovative and creative, international students had many ideas to create a better life and give out benefit to others. Nevertheless, they were still not able to implement these ideas. Meanwhile, international students proved to have a fair play character that is deeply embedded in their psyche. It is derived from the statement of TA as follows:

"If I make mistake of course I will apologize."

The statement above indicated that they would apologize if they make a mistake and do not feel ashamed to admit it. Also, international students had an honest character that they dislike lying and always try be honest.

In this study, fair is assessed on how international students establish their social interaction with the people around. They made friends with anyone regardless of race, religion or culture. The following sentence was expressed by TA from Vietnam:

"I will not judge them, you know different religion different race means they have different background and I am really happy to meet them, to discover and to explore their culture."

In addition, international students stated that they have many friends from different religions and races, and they still uphold the tolerance. They considered that differences are their challenge to explore the culture of the people around.

Furthermore, instead of revealing the perception of international students on the conservation character of UNNES, this study also attempts to describe an international student opinion on the learning principle of Student Centred Learning (SCL) which is applied in UNNES. There are some indicators used as a benchmark for assessing how international students view SCL. The aspects studied include exemplary, equality, interactive, inspiring, participatory, integrative, comprehensive, implementable, contextual, educate, motivate, and learning by doing.

In the interview, international students in UNNES admired how the ideals exemplified by lecturers in teaching, including the dress code, etiquette, manners, and timeliness. However, an international student complained about professor who received phone calls while teaching and learning activities are conducted. According to him, received a phone call in the middle of the course created a little distraction and impolite. This statement was revealed by RB:

\section{".. but maybe sometimes they had call on their phone so maybe it was little bit disturbing."}

In the other hand, the principle of equality has been implemented properly by the lecturers at UNNES. International students argued that their lecturers treat them on par with other students. In teaching and learning activities, guidance, and when a student needed help, their lecturers did not discriminate their treatment between Indonesian students and international students.

"Our lecturer cannot speak English, so they never ask us some question."

However, international students of UNNES assumed that few professors were not interactive. This opinion supports the results obtained by Sato and Hodge (2015) who found that professors who teach international students tend to use passive teaching style than active teaching style in the class. International students assumed that limited ability of few lecturers in using English presumably created this barrier. On the other 
hand, there were few professors overcome this barrier by using images to provide insight to the international students that enabled them to understand the material presented:

"Yup, they explain...if they don't understand or if they cannot explain then they will show the picture."

Inspiring is the aspect that has not been fully earned by international students in the learning activities they join in. They considered that communication between students and lecturers only happened in academic issues only. However, some thought that they had enough inspiration from their lecturers because they encourage international students to be more enthusiasm in the learning activity. Thus, the international students had motivation to learn at UNNES, as expressed by an international student below:

"In the classroom, lecturers said Esma you can do it you can do it, ... Insha Allah Esma you can, you're incredible ... it makes me more enthusiastic."

Some international students also agreed that their lecturers had applied a participatory learning process. However, there were some passive and boring classes. Language constraint created this issue in which international students presumed that their professors did not apply participative principle in the class because of their limited English skill. Nevertheless, they admitted that learning activity at UNNES had applied the principles of integrative and comprehensive. According to participants, their lecturers welcomed for any discussion, both formally and informally, and able to give relevant explanations in lectures and guidance activities. This is in contrary to Sawir, et al (2007) who revealed that most international students experience isolation and loneliness.

The principle of implementable has been implemented by several professors that they did what they teach their students. Similarly, about the contextual principle. International students presumed that the lecturer could associate the lecture material with visual culture and manners. Therefore, learning by doing concept was implemented properly, as expressed by the following participants when explaining the principle of learning by doing in the Arabic class:

"For instance, if we enter the classroom, we greet first, pray first, right? ... The professor used to say hello, good morning, and then we pray that our study will be useful. After the lecture, we pray hamdalah, or (read) fatikhah... "

Generally, international students supported conservation-based curriculum and learning SCL principles implemented at UNNES. There are some obstacles encountered in the implementation process, notably the language constraints. Few lecturers had not been able to organize active communication in English with international students, and thus what is taught cannot be maximally accepted by the students. This finding was similar with the research of Rawjee and Reddy (2012). They stated that international students studying at a university in South Africa admitted the limited communication of lecturer-student, therefore they are not optimally join the learning activities.

The existence of International Office (IO) at UNNES has also not been able to assist the international students in studying at UNNES. 10 existence was still not maximized; hence international students did not gain significant benefit from the 10 . Therefore, it was expected that 10 executes its role in moderating international students in the teaching and learning activities and create mutual understanding and convenience for all parties. Such recommendation was also proposed by Sato and Hodge (2015), Rawjee and Reddy (2012) and Sawir, etc (2007), who emphasized the importance of cultural awareness programs, international student organizations and communication to support international students adapt with the campus environment.

Meanwhile, the manager of $1 O$ should understand what the desires of international students are, because the program of Darmasiswa is kind of product offered to consumers (international students). Therefore, knowing their sentiments toward products can truly help 10 to develop Darmasiswa programs and expand international cooperation with other parties (Hoof and Varbeeten, 2005).

\section{CONCLUSION}

\subsection{Conclusion}

The existence of international students at Universitas Negeri Semarang (UNNES) can be an indicator of the extent to which the achievement of the vision carried out by UNNES, which is international reputation. Based on the results, international students were able to adapt well at UNNES environment, both in academic and social issues. International students understood and implemented 8 conservation characters of UNNES; there are inspiring, humanism, caring, innovative, creative, fair play, honest and fair. 
Meanwhile, perceptions of international students to Student Centred Learning (SCL) applied at UNNES was measured by exemplary, equality, interactive, inspiring, participatory, integrative, comprehensive, implementable, contextual, educate, motivate, and learning by doing aspect. International students really appreciated the concept of SCL and stated that the learning principles had been implemented well at UNNES. Nevertheless, language remained a constraint, and thus interactive and participatory principles could not optimally be executed.

\subsection{Recommendation}

The existence of International Office (IO) at UNNES has not maximally run its role of being a mediator between international students and UNNES. Therefore, IO UNNES need to further demonstrate its role in creating mutual understanding between the two parties and providing facilities for international students to adapt UNNES environment. Meanwhile, few lecturers should improve their English to overcome language constraint and create participative communication with their international students.

\section{REFERENCE LIST}

BPM Unnes. 2015. Kurikulum Unnes 2015, Selaras dengan KKNI dan Konservasi. Presentasi, delivered on Program Pengenalan Akademik (PPA) in 2015. Downloaded from http://bpm.unnes.ac.id/download/on 19 March 2016 at 21:59 WIB.

Brown. L. 2008. The Incidence of Study-Related Stress in International Students in the Initial Stage of the International Sojourn. Journal ofStudies in International Education, 12: 1-6.

Gerungan. 1991. Psikologi Sosial. Bandung: Eresco

Robie, C. \& Ryan, A. M. 1996. Structural Equivalence of a Measure of Cross-Cultural Adjustment. Educational and Psychological Measurement, 56, 514-521.

Sato, Takahiro and Hodge, Samuel. R. 2015. Japanese Exchange Students' Academic and Social Struggles at an American University. Journal of International Students. Volume 5, Issue 3. Pp. 208-227. Downloaded fromhttp://iistudents.org/on 19 February 2016 at 11:23 WIB

Merton, R. K. (1948) The self-fulfilling prophecy, The Antioch Review, 8, 193-210

Sawir, Erlenawati, et al. 2007. Lonelines and International Students: An Australian Study. Journal of Studies in Iternational Education, Vol. XX No. X, Season XXXX, DOI: 10.1177/1028315307299699. Downloaded on 25 February 2016 at 10:56 WIB.

Sapoetra, Karta. 1987.Sosiologi Umum. Jakarta: Bina Aksara.

Smith, Jonathan A., Flowers, Paul., and Larkin. Michael. 2009. Interpretative phenomenological analysis: Theory, method and research. Los Angeles, London, New Delhi, Singapore, Washington: Sage.

Soekanto, Soerjono. 2000. Sosiologi Suatu Pengantar. Jakarta: PT Raja Grafindo Persada.

Suparlan, Parsudi. (1993). Manusia, Kebudayaan dan Lingkungannya. Jakarta

Winata, Andi. 2014. Adaptasi Sosial Mahasiswa Rantau dalam Mencapai Prestasi Akademik. Skripsi. Bengkulu: Faculty of Social and Politics Science, Bengkulu University. 